LSP International Journal, Vol. 7, Issue 1, 2020, 121-133

(C) Universiti Teknologi Malaysia

E-ISSN 2601-002X

DOI: https://doi.org/10.11113/lspi.v7n1.101

\title{
Quality Teaching Practice: Value Education in the Language Classroom
}

\author{
Tan Yuan Yi \\ Sekolah Menengah Kebangsaan Dato Jaafar, Johor Bahru, Johor, Malaysia \\ Norhanim Abdul Samat \\ Language Academy, Universiti Teknologi Malaysia, 81310 UTM Johor Bahru, Johor, Malaysia \\ Submitted: 10/01/2020. Revised edition: 25/06/2019. Accepted: 28/06/2020. Published online: 30/06/2020
}

\begin{abstract}
The latest Malaysian Educational Blueprint (2013-2025) asserts the importance of producing value-driven Malaysians through education. English language teaching should be aimed beyond producing more proficient users as it possesses a nature that is particularly suitable for value incorporation. This research aims to investigate how English teachers communicate values to students, the kinds of values communicated and whether the values communicated are stipulated by the Ministry of Education. This research utilized a qualitative case study approach on two respondents, an experienced English teacher and a novice English teacher. Their lessons were videotaped, transcribed and coded based on a set of established analysis tool. Semistructured interviews were also conducted to further understand the values depicted by the respondents. The results of the research show that teachers consciously incorporated values through selected topics, tasks and explicit moral statements. They subconsciously transmitted values through classroom rules and regulations, curricular substructures and expressive morality. It is found in this research that teachers applied much more subconscious approaches to communicate values than that of conscious ones during teacher-student encounter, with classroom facilitation being used as the medium most frequently. The kinds of values communicated included spiritual, intellectual, esthetical, positive, interactional, citizen, economical and modernized values. About half of the values communicated were stipulated by the Ministry of Education. This research provides new insights into how Malaysian English teachers can improve the quality of their teaching by harnessing the full potential of a language classroom to educate values.
\end{abstract}

Keywords: Value, value education, ESL, case study

\subsection{INTRODUCTION}

Value education in schools has become a growing concern and a research-worthy topic as deemed by educational researchers from all over the world. The cultivation of values amongst youngsters is in favour of the world's development (Robinson and Moulton, 2005; Zajda, 2018). Value education promotes improved civilization, cultural maturity, humanization, peace and spirituality, it is one of

*Correspondence to: Norhanim Abd Samat (email: norhanim@utm.my) 
the building pillars of a better world to live in. In fact, a value-based education has shown that it can the building pillars of a better world to live in. In fact, a value-based education has shown that it can inspire, drive, and equip learners with adequate skills, appreciation, and values to ensure a sustainable future can be produced (Merritt, Hale \& Archambault, 2018).

Currently, the value-educating responsibility in Malaysian schools is still largely shouldered by administrative teachers such as the principal and the senior assistant of student affairs, appointed disciplinary teachers, form teachers, religious teachers and moral education teachers. In actual sense, as much as the society claims that value education from home and from school are of equal importance, this responsibility should also be shared among all school teachers regardless of positions and subjects. As stated by Narvaze and Lapsley (2006), teachers should focus not only on how to facilitate academic learning but also how to mould students' characters. In fact, all teachers are in charge of the execution of national educational policy and the positive shift of the society (Crookes, 2003).

Furthermore, the English Language Teaching (ELT) that is particularly rich in value education resources cultivates not only the four skills and communicative ability, but also characterizations and beliefs that are morally upright. According to Asif et al. (2020), the language classroom is a suitable setting for cultivating the objective of a value or moral education, however, the integration into ESL or EFL textbooks and classrooms is still in its early stages but has the potential to promote globalization as well as intercultural and international communication. It is believed that if values are conveyed through ELT in a proper and effective way, Malaysian students who generally receive at least 12 years of formal English education would benefit profoundly from it. In the long run, the nation will savour betterment from the improvement of individual morality.

In the Malaysian Educational Blueprint (2013-2025), the ministry has identified 11 necessary shifts to transform the current education system. Shift three (3) asserts the importance of producing value-driven Malaysians through education. However, Ghafar et al. (2011)'s study on the application of Malaysian Secondary School Integrated Curriculum (KBSM) reveals that Bahasa Malaysia teachers' implementation of moral values is only at the medium level. In fact, many teachers at school including English teachers do not view "moral values" as written in their lesson plans important when it comes to real teaching.

The purpose of this paper is to examine the incorporation of values in English lessons taught by an experienced teacher and a novice teacher. In addition, the differences between the valueeducating practices of the two teachers will be highlighted.

\section{RELATED WORKS}

This paper explores the dominant aspects of the value incorporation in ELT, namely, the definition and the importance of values in teaching. 


\section{Definition of Values}

Halstead and Taylor (1996) define values as "things which are considered good" (p.5) and things that are well-liked by the society. Allport (1961) and Thomas (1997) both state that moral values are the beliefs that motivate people to act in certain ways. This echoes with the account made by Kluckkholm and Strodtbeck (1961) and Williams (1968), whereby values make up the criteria to be considered by an individual when deciding on the ways he would use to achieve his aims or to solve problems. To sum up, people's decisions and actions are highly susceptible to their value system. In other words, people tend to observe the values in their belief system when doing something or interacting with others.

\section{Importance of Values in Teaching}

Hussin (1989) addresses the importance of the teaching and learning of values especially in the Kurikulum Bersepadu Sekolah Menengah (KBSM) context. The following are his claims (p.36-39):

i. The teaching of spiritual values such as sympathy, understanding and cherishing the nature aims to implant ethical codes and actions amongst. It also portrays good behaviour and morality as required by the national principles.

ii. The teaching of intellectual values such as logical thinking, scientific thinking, rational thinking and critical thinking enables students to solve problems wisely and keep up-to-date with civil development.

iii. The teaching of esthetical values such as art of music and dance encourages students to be more focused and creative.

iv. The teaching of positive values such as perseverance, being productive, brave and competitive builds individuals who are able to contribute to the country.

v. The teaching of interactional values such as cooperation, tolerance, being friendly, respect for others, honesty and sincerity shapes students' realization on the importance of peace.

vi. The teaching of political and citizen values such as supremacy of the institution cultivates patriotic, civilized and loyal citizens.

vii. The teaching of economical values motivates students to work hard to improve their own life qualities and the economy of the country.

viii. The teaching of sociocultural values raises the awareness of embracing different cultures among students.

ix. The teaching of modernized values such as being productive, environmental cleanliness and knowledge produce students who are concerned about the truth and the modernization of the country.

The above statements are in accordance with Mitias' (1992) who points out that "moral education fosters character development" (p. 1). In general, it is important to teach values because it nurtures students in different aspects such as spirituality and intellectuality. Apart from cultivating better human beings in the future, teaching of values also serves to solve current conflicts. This 
matches Haydon's (1997) description about values, which is a "conflict-avoidance device" (p.41) that can help to overcome the limitations of human beings in terms of intellectual and emotional intelligence.

\section{Importance of Values in English Language Teaching (ELT)}

The discussion of this section will focus on the advantages brought about by the incorporation of moral values in ELT. To begin with, incorporating moral values in ELT can help towards achieving Shift Three (3) of the Malaysia Education Blueprint (2013-2025), to develop value-driven Malaysians. It is hoped that students graduate with universal values, a strong Malaysian identity, a higher level of tolerance when dealing with people from different cultures, integrity, good citizenship and leadership. In line with that, Schuitema's et al. (2008) acknowledge the importance of value education in imparting skills on how to think critically, to solve problems, to take perspective, to make decisions and to communicate reflection.

According to Shaaban (2005), as English is widely used in various academic disciplines and professional fields across the world, it would be good to infuse professional ethics through English classrooms for betterment of human lives. Learning a language is equal to learning a new set of behaviours. If the pragmatic and value aspects are well imparted by the language teacher, it is not impossible to make learners alert of their professional ethics when they are using the language learnt in their respective workplaces (Asif et al. 2020). At the least, they learn to communicate in a polite manner. In other words, we can expect to have better engineers, lawyers, teachers, doctors and so on through inculcating moral values in their English classes.

\section{Conscious Incorporation of Values in Teaching}

Conscious incorporation of values is similar to the "teaching of morality". Akbari and Tajik (2012) state that "teaching of morality" happens when moral education stands alone as an independent subject in school. Jackson's et al. (1993) moral taxonomy categorized teachers' actions as the "teaching of morality". It seems appropriate then to define "teaching of morality" as the teaching practice of moral education teachers as well as that of non-moral education teachers when they consciously try to communicate certain moral values within the lesson. Narvaze and Lapsley (2006) term teaching of morality as the "minimalist" strategy whereby teachers make the hidden moral values explicit and show clearly the link between instructions and moral character outcomes.

English teachers can make use of a wide range of resources to educate values. For example, Shaaban (2005) proposed a framework to conduct the "teaching of morality" through ESL classes. The framework suggests several resources such as fairy tales, literature, art, history, internet and multimedia as well as community service to be adopted and adapted by English teachers to impart different moral values. In addition, themes and topics that are related to global development generally embody moral meanings; hence, a valuable resource to be harnessed by English teachers (Shaaban, 2005). Additionally, other content areas that are suitable for the teaching of morality include cultural issues, mankind development and Islamic studies (Shaaban, 2005; Asif et al. 2020). 
The teaching of morality or in other words, conscious incorporation of values refers to how a teacher communicates certain moral values that he wants the students to know in an obvious and direct way. Narvaze and Lapsleys' (2006) definition on the teaching of morality was adapted to come up with the themes, value-based topics, value-embedded English learning tasks and explicit statements on values. For example, purposely bringing up a value-based topic such as an article about the importance of physical cleanliness or making explicit statements on certain moral principles such as "physical cleanliness is important for everyone". In other words, this is where the teacher consciously intends to communicate a certain moral value. These examples are not sourced from current or other studies. They are purely our own examples to aid readers' understanding.

\section{RESEARCH PROCEDURES}

This research adopted a qualitative case study approach. As defined by Krathwohl (1993), qualitative research focuses on the description of a central phenomenon in words. In this case, the central phenomenon refers to the ways used by teachers to incorporate values in English language classroom. The purpose of choosing qualitative approach to conduct this study is due to the suitability of qualitative research in "understanding and interpreting social interactions" (Lichtman, 2006, p.7). In line with that, a case study sets out to investigate a phenomenon "within its real-life context" (Yin, 2009 , p.18). As we were seeking to explore the value incorporation in English classroom teachings and teacher-student encounters, it largely involved real-life social interaction among teachers and students, which justifies why a qualitative case study approach would equip this study more thoroughly.

Two English classes taught by two different teachers were involved in this study. The classes were observed and videotaped. The two teacher respondents were then interviewed using stimulatedrecall methodology. As defined by Gass and Mackey (2000), stimulated recall is aimed to discover respondents' thought processes after they have performed an activity. It is usually done with certain extent of support, for example, showing a videotape of how they carried out the said activity. Since the interview questions were closely related to the lessons, the videotaped lessons were played alongside the interview.

Specific transcripts of the lessons were coded based on a data analysis tool categorized below.

Table 1 Data analysis tool

\begin{tabular}{ll}
\hline Categories & $\begin{array}{l}\text { Conscious incorporation of values } \\
\text { (Narvaze and Lapsley,2006) }\end{array}$ \\
\hline Themes & Value-based topics \\
& Value-embedded English learning task \\
& Explicit statements on moral principles \\
\hline
\end{tabular}


According to Cresswell (2012), codes refer to labels used to represent a segment of transcript. The coding process was divided into two, the first was more general in nature whereby we sorted out the transcripts into segments of general information. After coding the data, the occurrence of each theme was counted and divided by the total number of occurrences sum up from all themes to obtain a particular percentage. Eventually, the percentages of all sub-themes were summed up to calculate the overall percentage of the main themes.

Data was derived from an experienced English teacher (Respondent A) and a novice English teacher (Respondent B) who were selected as the respondents of this study. The former has 30 years of teaching experience whereas the latter has been teaching for only a year. The reason for choosing an experienced teacher and a novice teacher is to compare their practice in value incorporation. A study was conducted by Akbari and Tajik (2012) to compare the moral knowledge base between experienced and inexperienced teachers and significant differences have been found. Therefore, we were interested to find out the difference between experienced and novice Malaysian English teachers when incorporating values in their classroom teachings.

\section{RESULTS AND DISCUSSION}

This section presents the findings of this study and is organized based on the key findings obtained from the analysis conducted.

\section{Values Incorporation in the Lesson}

In this section, the types and categories applied by the respondents to incorporate values in their lessons are analyzed based on the data analysis framework as proposed by Narvaze and Lapsley (2006). The following table presents a summary of the value incorporation in the respondents' lessons.

Table 2 Summary of value incorporation in respondents' lessons

\begin{tabular}{llll}
\hline $\begin{array}{l}\text { Categories of Value } \\
\text { Incorporation }\end{array}$ & Themes & $\begin{array}{l}\text { Respondent } \\
\mathbf{A}\end{array}$ & Respondent B \\
\hline & $\begin{array}{l}\text { Value-based topic } \\
\text { Value-embedded } \\
\text { learning task }\end{array}$ & $\sqrt{ }$ & $\sqrt{ }$ \\
$\begin{array}{l}\text { Explicit moral } \\
\text { statement } \\
\text { Expressive morality }\end{array}$ & $3.01 \%^{4}$ & $\sqrt{ }$ \\
& $4.22 \%^{\mathrm{a}}$ & $10.96 \%^{\mathrm{a}}$ \\
\hline
\end{tabular}

Conscious incorporation of values lies in the teaching of morality in an English lesson, as in how the teacher makes use of the lessons to convey good values. There are three themes of conscious 
value incorporation, namely, value-laden topics, English learning task employed and explicit moral statements.

Both respondents displayed awareness towards attributing the teaching of English in communicating values to the students. They shared similarity in choosing topics and English learning tasks that promotes value incorporation. Respondent A chose group work activity whereas Respondent B employed inquiry learning method by asking students to find out about their friends' problems. Nevertheless, Respondent B was keener in giving explicit moral statements as compared to Respondent A. The least frequent category used by Respondent A are explicit moral statement $(3.01 \%)$ and expressive morality $(4.22 \%)$ respectively. On the contrary, Respondent B incorporated values more often via explicit moral statement $(9.59 \%)$ and expressive morality $(10.96 \%)$. The details of each type and category will be discussed thoroughly in the following sections. Relevant excerpts from the interview transcripts will be used to support the discussion.

\title{
Value-based Topics
}

In general, both respondents used value-laden topics to teach English. They set out to convey certain values through the topics selected. For instance, Respondent A chose a current issue, massive flood in Kelantan as the backbone of the poster-designing and presentation activity. As students were asked to come up with four ways to help the flood victims, they were required to empathize with the victims' needy situations and be helpful to lend a hand practically.

\begin{abstract}
Respondent A: it's so happen that this is the current issue, whereby the flood situation in the east coast is quite bad... I want the students to empathize with the plights of the victims. So, I come up with the topic of how students can help to solve or to elevate or to lighten the burden of the flood victims.
\end{abstract}

Turn 10, Interview Transcript 1

As shown above, Respondent A expressed his empathy towards the flood victims. On the other hand, in Respondent B's lesson, a story entitled "The Law of the Garbage Truck" was used as the prior reading material before proceeding to the postcard writing activity.

Respondent B: the story was very positive and impactful to the students I think.

Turn 22, Interview Transcript 2

By using the story, Respondent B aimed to tell her students that it is normal to have problems in life and students should not let those problems take over their day. In addition, she related the story to another story about a mother and a son, which was also about positive thinking.

Respondent B: because that story is related to the current text and it was very meaningful to me...let's say I have problems, I will always think of this story so I wanted to share with the students.

Turn 28, Interview Transcript 2 
According to Respondent B, she shared that story with the students because she thinks it will benefit the students by shaping a more positive way of thinking.

\section{English Learning Task Employed}

Respondent A employed group work in his class in which students were asked to design and present their posters in groups of four. This is in line with Beanne's (2002, as cited in Schuitema, 2008) suggestion on how to teach morality in class as the task exposed students to cooperative learning. Students learnt how to work together towards producing the poster assigned by the teacher. Through this, the value of cooperation was taught.

Respondent B encouraged students to interview their friends to inquire about their friends' problems in order to give advice and moral support in the postcard written.

Respondent B: when they interview their friends they will be able to like, at least understand their friends a little bit more, and indirectly this will improve their relationship in the class.

Turn 32, Interview Transcript 2

The interview transcript revealed that Respondent B tried to empathize with their friends' problems and understand them more. This transcended the friendship values. The task is similar to inquiry learning which is recommended by Saye (1998, as cited in Schuitema et al., 2008) for teachers who would like to incorporate moral values in class.

\section{Explicit Moral Statements}

Explicit moral statement refers to the statements made by respondents that were consciously intended to send out a certain message or value to improve students' understanding.

Table 3 Comparison between respondent A and B on the use of explicit moral statements

\begin{tabular}{lll}
\hline Theme & Respondent A & Respondent B \\
\hline $\begin{array}{l}\text { Explicit moral } \\
\text { statement }\end{array}$ & $3.01 \%$ & $9.59 \%$ \\
\hline
\end{tabular}

As displayed in the table above, both teachers made use of explicit moral statements to convey values in oral form. However, it is found that Respondent B tended to rely on giving explicit moral statements a great deal more than Respondent A. Furthermore, generally, based on the lesson transcripts, Respondent A made longer moral statements than the other party. This difference could probably be explained by their different beliefs in the value-educating role of an English teacher. 
Respondent B: (...) I think not only English teachers, all teachers play a role in moral education.

(Turn 8. Interview Transcript 2)

The reason why Respondent B delivered a relatively higher percentage of explicit statements of moral principles in her lesson is because she believes that it is a teacher's obligation in order to bring positive influence. In accordance with that, she revealed a firm belief in the moral education role of an English teacher as shown above.

Besides, she expressly conveyed a story about a mother and a son to relate positive messages to her students. When asked about her opinion regarding the English teacher's role in teaching values, Respondent B explained,

Respondent B: I think it should be my previous English teacher, because I still remember some of the moral stories that she told us during school.

(Turn 10, Interview Transcript 2)

As revealed by Martin and Baldwins' (1994) study, the teaching beliefs of novice teachers are usually influenced by their own experience. Respondent B similarly expressed that her teaching practice is a reflection of how she had been taught as a student in the past. She replicated the ways used by her previous English teacher to educate values to her own students.

Respondent A, on the other hand, as supported by the interview findings, is not as positive as Respondent B with regard to the teacher's role in educating students about values.

Respondent A: (...) moral education per se, in the present English ...in the present secondary school context is not very pragmatic in the sense that because it has become very academic. Students tend to just use route method to memorize the moral values...

(Turn 4, Interview Transcript 1)

Based on the excerpt, he relates moral education literally to the Moral Education subject, or more commonly known as Pendidikan Moral, whereby students need to memorize the moral values in order to answer the examination questions. Indirectly, he was pointing out that the main role to teach values does not lie with the English teachers but with his Moral Education colleagues. This again aligns with Martin and Baldwin (1994)'s study which found that experienced teachers' teaching beliefs are affected by "particular teaching realities" (p.8), which specifically refers to the fact that values are not tested in English language examinations in Malaysian schools. Therefore, it is unsurprising to note Respondent A's lack of enthusiasm in directly communicating about values in his English class. Anyway, this does not mean that he is not aware of the opportunity to impart values in his English class, as the choice of topic and task reflected. The findings on explicit moral statement merely suggests that compared to Respondent B, giving explicit moral statements in an English classroom is less significant in Respondent A's perception. Similar to Melo's (2003) and Akbari and 
Tajik's (2012) studies, novice teachers view teaching as a value-based profession and perceive themselves as the "moral agent" in class more highly than those who are experienced.

Instead of giving a great deal of explicit moral statements, experienced teachers are more concerned with the pragmatic aspects such as seeking solutions to students' real-life problems. In the following part, the use of explicit moral statements in both teachers' lessons will be explained with selected examples.

Respondent A: (...) we are neighbours, you have to be friendly with your neighbours.

(Turn 12, Lesson Transcript 1A)

Respondent A was explaining how to help the flood victims. One of the examples given by him was to donate necessities to the victims. He described the flood victims in east coast Malaysia as neighbours that students should be friendly and help the neighbours whenever they are in trouble. Within this single statement, multiple values such as friendliness, helpfulness and generosity were transcended. Students would realize that although the east coast is somewhere far away, they still share a connection with the victims, which makes helping the victims an important and necessary thing to do.

Respondent A: (...) you can go on the internet, set up the online blog, or website...appeal, to people for donation, but of course you must get the approval of the government.

(Turn 28, Lesson Transcript 1A)

This statement was made while facilitating the students. Respondent A was trying to provide more examples on what the students could do to help the flood victims. He then emphasized that all these must be carried out with the government's approval. Through this statement, students would learn that they need to abide by the law when handling public monetary donation. It is also a significant value for teenagers in this modern era where technologies are often abused to share invalid information to acquire profit.

Respondent B: (...) when people have garbage, like he piles up a lot of garbage already right, so he will throw... but sometimes if he throw it to you, don't receive it, just be calm, just smile, then the garbage will not be on you.

(Turn 28, Lesson Transcript 2)

Respondent B was discussing the story with the class and came up with this statement. She advised students not to be affected by others' negative emotions, instead, they should deal with it calmly with a smile. Having heard this, students were exposed to the value of rationality. They would learn that there is no point arguing and getting angry with people who have lost their composure. As she clearly explains in the following extract from the interview. 
Respondent B: (...) when you set your heart to be positive, then everything will be fine. So that is like, today I say, when I wake up I say, today will be fine, so everything will be fine. It's all in your mind, all in your heart, so you decide your own weather, whether it's rain or shine, everything will be fine. So, this is the positive attitude that you need to have.

(Turn 85, Lesson Transcript 2)

\section{CONCLUSION}

This section presents the concluding statement that answers, "In what way do teachers communicate values to the students?" It is found in this study that both respondents communicated the values through conscious means. Both Respondents A and B used topics and learning tasks that are value embedded. The novice teacher used more explicit moral statements than her experienced counterpart. It is safe to conclude that fundamentally, teachers bring up value-laden topics and learning tasks to communicate values.

The findings of this study reflect that English teachers put less emphasis on expressive morality in their classroom talk. Expressive morality is not only effective in communicating values, but also useful for students to understand sarcasm in the target language culture, thus improving their communicative competence. It is recommended for English teachers to use more expressive morality in class by saying things indirectly with a slightly ironical sense of humour that students would learn to read between the lines and alter their behaviours without feeling as though they are being directly instructed to do so. It is also recommended that English teachers employ more classroom rules although they may not be the class teacher, to help shape students into better individuals in the future.

\section{REFERENCES}

Allport, G.W. 1961. Pattern and Growth in Personality. New York: Holt, Rinehart and Winston.

Akbari, R. and Tajik, L. 2012. Second-language Teachers' Moral Knowledge Base: A Comparison between Experienced and Less Experienced Male and Female Practitioners. Journal of Moral Education. 41(1): 39-59.

Asif, T., Guangming, O., Haider, M.A., Colomer, J., Kayani, S, and Amin, N. 2020 Moral Education for Sustainable Development: Comparison of University Teachers' Perceptions in China and Pakistan. Sustainability. 12: 3014.

Beane, J. A. 2002. Beyond Self-interest: A Democratic Core Curriculum. Educational Leadership, 59(7): 25-28.

Cresswell, J. W. 2012. Education Research: Planning, Conducting, and Evaluating Quantitative and Qualitative Research. $4^{\text {th }}$ ed. Boston: Pearson Publication.

Crookes, G. 2003. A Practicum in TESOL: Professional Development Through Teaching Practice. 
Cambridge University Press.

Gass, S. M. and Mackey, A. 2000. Stimulated Recall Methodology in Second Language Research. London: Lawrence Erlbaum Associates.

Ghafar et al. 2011. Integrated Curriculum Concepts on Malaysia: Knowledge and Application Differentiation. European Journal of Social Sciences. 19(2): 208-217.

Halstead, M. and Taylor, M. J. 1996. Values in Education and Education in Values. London: Falmer Press.

Haydon, G. 1997. Teaching About Values: A New Approach. London: Cassell.

Hussin, S. 1989. Pengajaran Nilai dalam Kurikulum. Petaling Jaya: Fajar Bakti.

Jackson, P. W., Boostrom, R. E. and Hansen, D. T. 1993. The Moral Life of Schools. San Francisco: Jossey-Bass Publishers.

Kluckholm, F. R. and Strodtbeck. F. L. 1961. Variations in Value Orientations. Row Peterson, Evanston, ILL.

Krathwohl, D. R. 1993. Methods of Educational and Social Science Research: An Integrated Approach.

New York: Longman.

Lichtman, M. 2006. Qualitative Research in Education: A User's Guide. California: Sage Publication.

Martin, N. K. and Baldwin, B. 1994. Beliefs Regarding Classroom Management Style: Differences between Novice and Experienced Teachers. Paper presented at the Annual Conference of the Southwest Educational Research Association.

Melo, P. 2003. Ethical Conflicts in Teaching, The Novice Teacher's Experience. Connections. 3: 175189.

Merritt, E. G., Hale, A., Archambault, L. 2018. Changes in Pre-service Teachers' Values, Sense of Agency, Motivation and Consumption Practices: A Case Study of an Education for Sustainability Course. Sustainability. 11: 155.

Ministry of Education. 2003. Huraian Sukatan Pelajaran Bahasa Inggeris Tingkatan 1-5. Retrieved 8 December, 2014, from http://jabatanbahasastar.wordpress.com/2011/07/16/sukatan-pelajaranhuraian-sukatan-pelajaran/.

Ministry of Education. 2013. Preliminary Report: Malaysia Education Blueprint 2013-2015. Retrieved 8 December, 2014, from http://www.moe.gov.my.

Mitias, M. H. 1992. Moral Education and the Liberal Acts. United Sates of America: Greenwood Press.

Narvaez, D. and Lapsley, K. 2006. Teaching Moral Characters: Two Strategies for Teacher Education. In Press, Teacher Educator.

Robinson, G. and Moulton, J. 2005. Ethical Problems in Higher Education. United States of America: iUniverse Inc.

Saye, J. W. 1998 Creating Time to Develop Student Thinking: Team-teaching with Technology. Social Education. 62(4): 356-362.

Shaaban, K. 2005. A Proposed Framework for Incorporating Moral Education into the ESL/EFL Classroom. Language, Culture and Curriculum. 18(2): 201-217.

Schuitema, J., Dam, G. T. and Veugelers, W. 2008 Teaching Strategies for Moral Education: A Review. Journal of Curriculum Studies. 40(1): 69-89. DOI: 10.1080/00220270701294210.

Thomas, E. L. W. Y. N. 1997. Teacher Education and Values Transmission: Cultural Dilemmas with 
Difficult Choices. Educational Dilemmas: Debate and Diversity. London: Cassell. 246-259. Wang, Z. 2009. Study on Countermeasure on Moral Education through School Network. US-China Education Review. 6(1): 44-48.

Williams, R. M. 1968. Values, in Sills, E., (ed.). International Encyclopedia of the Social Science. New York: Macmillan.

Yin, R. 2009 Case Study Research: Design and Methods. Fourth edition, Thousand Oaks, CA: Sage Publications.

Zajda, Joseph. 2018. Researching Values Education in the Classroom: A Global Perspective Education and Society. 36(2): 29-47. 